\title{
The implementation of nutrition improvement programs for underweight children, wasting and stunting in the Department of Health, Central Buton district, Southeast Sulawesi
}

\author{
Nur Wulandari ${ }^{{ }^{*}}$, Ani Margawati ${ }^{2}$, M. Zen Rahfiludin ${ }^{3}$
}

\begin{abstract}
Background: Health status can affect the Human Development Index (HDI) of a country. To improve the quality of human resources, the Indonesian Government has applied various policies, such as the nutrition improvement program, since there are still lots of toddlers suffering from underweight, wasting dan stunting. Even one out of three toddlers in Indonesia were detected stunting.

Objectives: This study described the implementation of a nutrition improvement program for toddlers in the Central Buton District Health Office.

Materials and Method: This was a qualitative study that involved ten informants. Three of those informants are nutritionists in the District Health Office, Head of Public Health Department, Head of NutritionDepartement. Also, two nutrition workers in primary healthcare centers and two mothers of malnourished toddlers.

Results: These findings showed that in terms of input, trained human resources on nutrition were lacking, and the budget for the nutrition improvement program was inadequate. While, in the process, all implementors had done very well, although they still had no collaboration across sectors. In the output aspect, the health status of underweight, wasting, and stunting toddlers improved. Also, monitoring and evaluation were conducted on toddlers registered at the integrated service posts in 2018.

Conclusions: There were still constraints on the input, process, and output aspects, even though there was an increase in the nutritional status of children under five, but nutrition problems for children under five in Central Buton Regency were still high.
\end{abstract}

Keywords: Nutritional improvement program; Toddlers; Implementation

\section{BACKGROUND}

Nutritional problem is a problem in the life cycle, starting from pregnancy, infants, toddlers, teens, to the elderly. The nutritional problem can occur in all age groups, even nutritional problems in a certain age group will affect nutritional status in the next life cycle (intergenerational impact). ${ }^{1}$

Indonesia nowadays is still faces nutritional problems such as underweight, wasting, and stunting, this can affect the quality of human resources, because growth constraints during toddlers have the potential to experience non-communicable diseases in adulthood. ${ }^{2}$ According to the President of the Republic of Indonesia, the fulfillment of nutrition is one of the best long-term investments that can be made, apart from requiring skilled human resources, of course, Indonesia also needs healthy human resources. The health status of a nation can affect the human development index (HDI), therefore the government is committed to making efforts to overcome various nutritional problems by issuing various policies on nutrition improvement. ${ }^{3}$

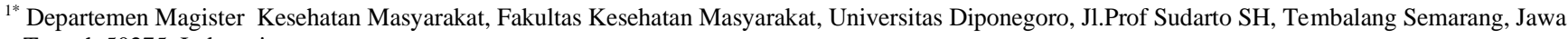
Tengah 50275, Indonesia

${ }^{2}$ Departemen Gizi, Fakultas Kedokteran, Universitas Diponegoro,Jl. Prof.Sudarto SH, Tembalang, Semarang, Jawa Tengah 50275, Indonesia

${ }^{3}$ Departemen Kesehatan Masyarakat, Fakultas Kesehatan Masyarakat Universitas Diponegoro, Jl. Prof Sudarto SH, Tembalang, Semarang , Jawa Tengah 50275, Indonesia

*Correspondence : e-mail: wulandrrynur@gmail.com
} 
Toddler age is a period where the process of growth and development occurs very rapidly, with high activity and learning changes. At this time the child's brain develops rapidly up to $80 \%$, so it requires sufficient nutrient intake in both quantity and quality, if the nutritional intake is not fulfilled, the physical and intellectual growth of toddlers will experience disruption, as a result, toddlers become lost generation, and can adversely affect the country due to the lack of quality human resources. ${ }^{4}$

In 2017, the number of children under five in Indonesia is around 22.4 million every year, there are at least 5.2 million women in Indonesia who are pregnant, so the average number of baby-born every year is 4.9 million, and baby with short birth conditions have the potential to the increase in the number of children under five with stunting, whereas in 2018 there were $17.8 \%$ of children under five suffering from malnutrition, $12.7 \%$ among under-five children with malnutrition, $12.7 \%$ of whom were short, for that intervention to reduce stunting would reduce under-nutrition Malnutrition) ${ }^{5}$

Stunting is a chronic nutritional problem caused by a lack of nutritional intake for a long time, characterized by a lack of height from the standard children in general, this occurs since the child is still in the womb until the age of 2 years or the first 1000 days of life and the child is stunted after 2 years of age cannot be changed anymore so what can be done is to maximize the potential for brain development. In contrast to stunting, malnutrition takes place in a shorter time, that is, when the child experiences normal growth up to a certain age, then there is a change in diet which causes the toddler to no longer getting enough intake, as a result, the child loses weight in a short time but the recovery also fast. Apart from stunting and malnutrition, There is also malnutrition, namely children under five who are underweight children of their age. Another nutritional problem is obesity or excess nutrition. Nutritional status is an important indicator for the health of children under five whose physical impact is measured anthropometry and categorized based on WHO standard with index weight/age, height/age, and body weight/height. ${ }^{6}$

The problem of child nutrition in Indonesia is very worrying because 1 in 3 Indonesian children is stunted, nationally the proportion of stunting among toddlers is $37.2 \%$ in 2013 to $30.8 \%$, in 2018 , the prevalence of under-nutrition is $19.6 \%$ years 2013 to $13.8 \%$ in 2018 , the prevalence of malnourished toddlers is $5.7 \%$ in
2013 to $3.9 \%$ in 2018 , the prevalence of underweight children is $12.1 \%$ in 2013 to $10.2 \%$ in 2018 while obese toddlers are $11,9 \%$ in 2013 to $8.0 \%$ in 2018, this is what then causes Indonesia to face a double burden. Although nationally from 2013 to 2018 there has been a decrease in the prevalence of nutritional problems in children under five, there are still gaps between provinces, especially the problem of stunting. ${ }^{7}$

The prevalence number of stunting at the provincial level is still very high, where 2 provinces have a stunting prevalence $>40 \%, 18$ provinces have a stunting prevalence of $30-40 \%$ and 23 provinces including Southeast Sulawesi have a stunting prevalence of 20$30 \%$, and only DKI Jakarta has a stunting prevalence < $20 \%$. Based on the results of monitoring the national nutritional status of Southeast Sulawesi in 2017, the highest stunting problem was in Central Buton Regency, namely $48.8 \%$ under five, $25.9 \%$ underweight, and $13.3 \%$ underweight. Also, the frequency of visits to children under five to the posyandu is decreasing along with the increasing age of the children, from 12,060 the number of children under five, with the coverage of under-fives weighed as much as 8,786 (73\%) and 3,247 (27.14\%) under-fives whose body weight is not monitored. ${ }^{8}$

Toddlers as the assets of our future (nation) must receive optimal nutritional care and attention as a series of individual and community nutritional needs through prevention, improvement, healing, and recovery efforts carried out in the community and health service facilities, including involving related sectors. ${ }^{9}$ The central government gives authority to the provincial government which then the provincial government delegates to the city/regency government to be responsible for implementing efforts to improve nutrition. Based on the results of the field study, Central Buton is one of the districts in Southeast Sulawesi which is responsible for implementing the nutrition improvement program. The programs that have been implemented include monitoring the growth of toddlers at the health center, providing additional food, and tracking cases of toddler nutrition, this is done based on the regulation by the Indonesian Minister of Health no. 23 of 2014, to improve food consumption patterns following balanced nutrition improving behavior awareness of nutrition, physical activity, and health. ${ }^{10,11}$ Based on this situation, the authors are interested in describing the implementation of the toddler nutrition improvement program which consists of early detection of the status of children under five years old in the 
Central Buton District through system elements consisting of Input, Process, and Output.

\section{MATERIALS AND METHODS}

This research is an observational study with a qualitative descriptive design, which was conducted in September 2018 - August 2019. The subjects of this study were nutrition staff and mothers of malnutrition children under five years old in the work area of the Health Office of Central Buton District, Southeast Sulawesi Province. The selection of informants was carried out by using the purposive sampling technique by observing. Data collection methods were obtained through in-depth interviews, observation, and documentation of 10 informants consisting of 3 main nutrition staff informants (IU1, IU2, IU3) of the Health Office, and data validity was carried out on 7 triangulation informants consisting of the Head of the Department Health (IT1), Head of Public Health (IT2), Head of the Family Health and Nutrition Section (IT3), 2 Nutrition Implementers of Puskesmas (IT4, and IT5), and 2 mothers under five years old with malnutrition (IT6, and IT7). The data collected includes system elements in a program policy consisting of input elements which include human resources, infrastructure, and funds used in implementing the nutrition improvement program for children under five years old, especially monitoring the nutritional status of toddlers, next is the process element which includes planning, organizing, implementing, and monitoring evaluation. In addition to the two elements of input and process, there is also a third element, namely output as a reference to determine the success of the nutrition improvement program for children under five at the Health Office of Central Buton District, Southeast Sulawesi Province, where the nutritional status of children is assessed based on the Body Weight (BW) / Age (A) index which is categorized as undernutrition (Underweight), good nutrition and more nutrition. Body Height (BH) / Age (A) children were categorized as very short, short, and normal. Furthermore, the weight/height of children is categorized as very thin, thin, normal, and obese. This is based on the z-score according to the standard deviation value of growth according to the World Health Organization (WHO). Data analysis techniques in this study were carried out with data collection, data reduction, data display, and conclusion.

\section{RESULTS}

Central Buton Regency is one of the regencies in Southeast Sulawesi which consists of 7 districts. The Health Office is one of the elements implementing government affairs that is tasked with helping the regent carry out government affairs, especially in the health sector, this is stated in the Central Buton Regent Regulation No.13 of 2018 concerning the Position of the Organizational Structure, Duties and Functions and Work Procedure of the Health Service of Central Buton Regency. The Health Office consists of several fields, one of which is the public health sector, including a section of nutrition and family health which is responsible for running community nutrition improvement programs and carrying out coaching and cooperation with health centers in implementing community nutrition programs. maternal and child health services as well as other tasks related to family health and community nutrition. In this study, the authors focus on discussion with several aspects by a systems approach to be able to get an overview of the implementation of early detection programs and monitoring of the nutritional status of toddlers because a program will run well if it meets the target input, process and output indicators.

\section{Input}

\section{Human Resources}

The results of the interview on the implementation of the nutrition improvement program for children under five years old at the Health Office of Central Buton District based on the input element seen from the perspective of human resources (HR), that those involved in the nutrition improvement program were the Head of the Public Health Sector as the person in charge of the program, the head of the Family Health and Community Nutrition section. A program manager, and nutrition staff serving as report compilers and field technical advisors, and health center nutrition implementing staff (TPG) as executors of program activities. Human resources are people who are responsible for and coordinate the implementation of a program. Following are the results of interviews about human resources:

Based on the results, it was found that the nutrition staff of the Health Office was 3 people, 2 were civil servants (PNS), but one of them had never attended training on nutrition because only 6 months had worked as a nutrition staff at the health office and 1 person was still as an intern, the head of the family health and nutrition section that has an educational background (Diploma/DIII) in Midwifery with a long term of 4 years in the health department. The head of the public health sector has an educational background (Diploma/DI) Nutrition department, has served for 2 
years, and the Head of the Health Office with a 2 years term. Nutrition staff at the Health Office can be said to be still lacking because at one time the nutrition staff who were still as an intern to become the person in charge of the nutrition improvement program, and the nutrition staff could get over-work. Besides, there is nutrition staff who have never attended training, especially training on nutrition during their time as nutrition staff at the Health Office.

IU1: the staff is still lacking, because we are only three of us, 1 is still an apprentice, but has worked 4 years and has attended training on nutrition, and 2 people are civil servants (PNS), but one of them has only worked for 6 months and has never attended any training while working at the health office, especially regarding nutrition, so sometimes we feel overwhelmed if suddenly there are reports of cases of malnutrition at the same time from various subdistricts, and the three of us and have to do tracking, some are doing intervention, field technical guidance and making nutrition reports to be accountable to during the evaluation meeting.

IT3: actually still lacking, because usually the person holding and responsible for one of the programs is an apprentice staff, as well as providing field technical guidance.

So it can be concluded that the nutrition staff at the Central Buton District Health Office in terms of quality and quantity is still not under the Minister of Health Regulation No. 26/2013 concerning the Implementation of Work and Practices for Nutritionists in Service Centers in section 17 states that nutrition workers in implementing nutrition services in health service facilities have the authority to participate in education, training, research and development of nutrition services. ${ }^{12}$

2. Facilities and infrastructure

Based on the results of interviews and observations of facilities and infrastructure, there were no obstacles in the provision of infrastructure because, in terms of the procurement of all supporting facilities, they were well maintained and available at the Health Office and the Puskesmas. The tools available consist of anthropometric tools, toddler weight scales, writing instruments, digital weighing devices, and height measurement tools, KMS (public health) books, recording and reporting forms, technical instructions for program implementation, additional food and medicines (vitamin A), which was available at the posyandu. Also, the District Health Office validates health service facilities based on a predetermined operational permit. Validation is done by comparing the suitability of the condition of the medical equipment facilities and infrastructure needed in the field and those available in health service facilities. Following are the results of interviews with key informants and triangulation.

IU2: for the too-provision by the government (Dinas) then distributed to each puskesmas, however, there must be a report if the puskesmas needs/changes equipment, and if food for toddlers is malnutrition or lacking, usually the Health Office provides instant food such as biscuits, while the puskesmas works together Posyandu cadres provide local food, porridge, eggs and so on, and there are no obstacles in the provision of facilities and infrastructure at the Health Office.

IT2: anthropometric equipment is usually the agency that provides according to the needs of the puskesmas, and so far there have been no obstacles in the procurement of sarpras because there is always coordination and validation of medical devices in health services between the office and the puskesmas.

\section{Fund}

One of the components of the resources needed in organizing a health program is health financing or funds. Based on the results of interviews from the three nutrition staff at the Health Office, it was stated that the nutrition improvement program had been budgeted for in the Central Buton Regency (APBD), but because of the reduction or rationalization of the APBD, not all activities from the nutrition improvement program received a budget, such as socialization on nutrition problems for children under five years old such as stunting. the stakeholders who have an important role in the success of the program cannot be done because the funds have not been programmed and are not sufficient. Following are the results of interviews with key informants and triangulations.

\section{Process}

\section{Planning}

Planning is the basis of the process of implementing a program, so it must be formulated and conveyed so that the results are following the desired objectives.

The planning process for the nutrition improvement program for children under five at the Health Office of 
Central Buton District consists of human resource planning, implementation plans, budget plans, and monitoring and evaluation plans. Following are the results of interviews with informants.

Based on the results of the interview and data from budget planning book-keeping that there is a harmony between the statements of the main informant and the triangulation informant, it can be said that planning on the implementation of the nutrition improvement program for children under five years old has been carried out by the Health Office of Central Buton District so that program implementation can run well and achieve maximum results.

2. Organizing

Organizing is the process of preparing an organizational structure under the goals of the organization, its resources, and the environment. Organizing is very necessary to facilitate the implementation of programs that have been previously formulated in planning. The organization of the nutrition improvement program for children under five years old at the Health Office of Central Buton District is described in several stages, namely the division of tasks, the appointment of a coordinator, and the activities to be carried out. Following are the results of interviews with key informants and triangulation

IU3: for the organizational structure, the implementation of the nutrition improvement program at the health office is in accordance with the organizational structure of the head of the service, in charge of the community health sector, coordinating the family health and nutrition section and nutrition staff as executors and monitoring whether or not the program is running at the puskesmas level because it is the party fully implementing it puskesmas, assisted by posyandu cadres because the target is toddlers with nutritional problems. The activities are monitoring the growth of children under five, providing additional food, and nutrition counseling. Most of the activities are carried out at the posyandu, besides that, the puskesmas collaborates with villages/sub-districts to provide additional food so that nutritional problems such as malnutrition, malnutrition and stunting are reduced.

IT4: because the service as a monitor is not the implementer, so we always involve the puskesmas in its implementation, starting with the posyandu cadres, who report a problem to the puskesmas, then the puskesmas reports the problem to the health office, the office makes an activity plan citing the problem, then then reported to the government, in order to get support from both material and non-material.

\section{Implementation}

An implementation is an act of striving for all members involved in the program to achieve predetermined goals by their respective main tasks in planning. In the program for the implementation of nutrition improvement activities in the working area of the Health Office of Central Buton District, monitoring the growth of children under five at the posyandu, providing additional feeding for toddlers, and tracking cases. Following are the results of interviews with key informants and triangulation

IU1: It is still lacking because the nutrition improvement program has a variety of activities, so we are smart about using it, if the priority is usually we still try to do it with these funds, but we cannot do socialization so that we cannot work together with other sectors. outside of health to solve nutritional problems under five years old.

IT2: It is enough but there is still more supervision for funding program implementation, because there is a reduction or rationalization of the APBD Budget.

IU1: this nutrition improvement activity is carried out to reduce nutritional problems and improve nutritional status, so it must involve many people such as the head of the public health, head of health and nutrition, nutrition staff, health center nutrition officers, medical personnel, cross-program medics and posyandu cadres, all sources the power to work together to improve the nutritional status of toddlers, such as pmt in posyandu, toddler nutrition screening or toddler nutrition tracking, For our own budget plans, for example for next year's budget, we must input this year's report, even then the funds we include in the activity report, are usually not suitable with the funds we get, then again we determine priority activities then the budget is put in dpa, while monitoring is carried out every quarter.

IT1: us and the puskesmas, and the community are trying to coordinate so that the implementation of nutrition improvement programs and other programs runs well according to the desired results

IT3: nutrition staff as the person in charge of the program in the department, nutrition implementing staff at the health center in charge of the puskesmas level, cadres, medical personnel, environmental health, for budget planning, the range I forget to look at later in the bookkeeping, because it is the nutrition staff who compile the budget. We plan to evaluate the evaluation once a year, because we also do monitoring every three months, so from monitoring we can correct any mistakes in implementation.

Copyright (C) 2021; Jurnal Gizi Indonesia (The Indonesian Journal of Nutrition), Volume 9 (2), 2021

e-ISSN : 2338-3119, p-ISSN: 1858-4942 
From the interview result with the nutrition staff as the main informant (IU1) and health center nutrition executives as triangulation informants (IT4), it was stated that the implementation of monitoring of the nutritional status of children under five was carried out guided by posyandu cadres under the auspices of the puskesmas. In addition, the next activity is the selection of cases of malnutrition, along with the results of interviews with nutrition staff at the health office (IU2), health center nutrition staff (IT4), and mothers of malnourished children under five years old (IT7). In addition to monitoring at the posyandu, there was also a screening to find out malnourished toddlers at the posyandu, puskesmas, and even home visits intending to find cases of malnutrition under five years old by measuring body weight according to age (BW/A) and weight according to height $(\mathrm{BW} / \mathrm{BH})$, as well as the presence of clinical signs such as abdominal disease. Also, the program for the improvement of nutrition for children under five is providing additional food for children under five. Following are the results of interviews with nutrition staff from the health office (IU3), TPG nutrition at the puskesmas (IT5), and mothers of malnourished children under five (IT7).

IU1: For nutritional status monitoring, it is done at the posyandu, if the office is just waiting for a report from the puskesmas if cases of malnutrition are found, so we only monitor what the puskesmas do.

IT4: We do monitoring the nutritional status of toddlers with cadres, like weighing them, because from weighing we can know whether there is a nutritional problem or not, but for malnutrition, we monitor it once a week by making home visits for 3 months.

4. Evaluation Monitoring

Monitoring and evaluation are carried out to determine performance in program implementation and to find out how the achievements of activities that have been implemented. The evaluation referred to in this paper is the evaluation and monitoring by the health office of the puskesmas as the field implementer in the nutrition improvement program for children under five at the Health Office of Central Buton District. Following are the results of interviews with key informants and triangulation informants.

From the statement of the nutrition staff as the main informant (IU1) and the head of the health department as the triangulation informant (IT1), that monitoring is carried out to determine the course of an activity, to prevent and minimize problems in the field, apart from monitoring the Health Office also evaluates the implementation of nutrition improvement programs. Following are the results of interviews with key informants and triangulation informants.

IU2: usually also done during the inspection at the posyandu, at the puskesmas, and even at home visits to find cases of malnutrition under five years old, usually due to lack of nutritious food intake and congenital diseases.

IT4: We conduct home visits if there are reports of cases of malnutrition, from posyandu cadres, for the counseling to be conducted every two months, even nutrition cases can also be obtained from the puskesmas, when a child being examined for health at the puskesmas is suspected of suffering from malnutrition.

IT7: So every time you weigh it at the clinic, your body weight does not increase, sometimes it goes down from the previous scale, you were also sick and then you were taken to the health center.

IU3-DKK: pmt is given on the guidance by cadres who work closely with the health center nutrition officers, but the materials are from the office such as biscuits, then the service distributes them to each puskesmas, later the puskesmas will be distributed at the posyandu, but usually for the posyandu we always recommend pmt in the form of local food.

IT5-PKM: after giving the pmt, we usually conduct counseling first to mothers of toddlers with nutritional status problems, to always provide food that contains energy and protein, as well as for the pmt that we provide if possible are sufficient for children who suffer from nutritional problems every day, and do not eat it by his brother or other people. Because pmt is only given to children who have nutritional status problems such as malnutrition, malnutrition, and stunting. But for toddlers with malnutrition cases once a week we check and monitor the child's weight at home for 90 days, besides that we are very helpful because the village is also involved in holding pmt.

IT6-IB: Every week the health worker visits the house, the child's weight is continuously measured, and given food, biscuits, packaged baby porridge, milk.

From the interview's result with nutrition staff at the Health Office as the main informant (IU3) and the head of the family health and nutrition section as triangulation informants (IT3), it was stated that the evaluation at the Health Office of Central Buton District was carried out to determine the performance achievements of activities. 


\section{DISCUSSION}

1. Human Resources

Human resources (HR) is an important aspect of implementing a program. Based on the results of the research, in carrying out the nutrition improvement program for children under five, it is carried out by the public health sector, especially the family health and

IU1: for field monitoring we usually do it by monitoring the results of reports from the puskesmas, from here we can see the progress of activities in the field, and if there are obstacles, while for monitoring at the service level we usually hold a meeting every quarter to find out about program progress and solve problems. which is a barrier to implementation

IT1: supervision is carried out in stages, from the head of the department, head of the field, head of sections and programmers, so that each of them reports the course of activities and the results obtained, and is reported at the periodic meeting every quarter.

IU-3: evaluation is carried out once a year, namely at the end of the year, if there are things that have not been achieved then we will go to the field to see, what are the obstacles, such as yesterday's coverage of under-fives weighing is still below the national target, so we are working with the health center to carry out a sweeping of under-five weighing each village / kelurahan in their respective puskesmas area, by mobilizing cadres to take notes and toddlers who do not participate in posyandu, so that at the next posyandu they can attend the posyandu

IT3: usually at the end of each year we hold an evaluation meeting to find out the results of the implementation of the program that has been running for almost a year, and compare whether the results obtained are on target, and take corrective action if the results are not on target, so that the following year can reach the target.

nutrition section of the Health Office of Central Buton District, but in its implementation, it involves the puskesmas and cadres, who are tasked with carrying outweighing activities for children under five at posyandu, providing additional food, tracking the nutrition of children under five, as well as other activities related to nutrition problems. Also, the results of the research show that the Health Office has limited human resources in the nutrition improvement program, both in terms of numbers, where there are only 3 nutrition staff, namely 2 civil servants (PNS), and 1 apprentice staff. If this is not done yet, it can become an obstacle in implementing the nutrition improvement program for children under five at the Health Office of Central Buton District. ${ }^{12}$ Based on previous research, there was a lack of health personnel resources at the Health Office of Central Buton District, especially nutrition staff, and there were still health centers that did not have nutrition workers, as well as inadequate access to roads so that they encountered obstacles in both the networking and tracking malnutrition activities. ${ }^{13}$

\section{Facilities and infrastructure}

Apart from competent human resources, supporting facilities and infrastructure are also needed in the implementation of nutrition improvement program activities for children under five. Based on the results obtained, the facilities and infrastructure for the nutrition improvement program for children under five in the working area of the Health Office of Central Buton District are complete, both at the puskesmas and posyandu, such as anthropometric tools, tables for posyandu implementation activities, besides that the posyandu also involves the role of the village in providing materials local food for supplementary feeding (PMT) in the form of eggs and green bean porridge, this is very influential in the success of the implementation of the nutrition improvement program for children under five. Although the number of active posyandu in Central Buton District decreased from 91 posyandu in 2017 to 85 (62\%) active posyandu in 2018, However, the level of awareness of mothers to invite their children to posyandu increased from $73 \%$ in 2017 to $85.7 \%$ in 2018 , this can be a picture of the maximum implementation of several priority posyandu programs, especially nutrition improvement programs. In line with previous research that posyandu is expected to be able to organize five priority programs, namely maternal and child health, family planning, nutrition improvement, immunization, and diarrhea prevention. Availability of adequate facilities and infrastructure, optimal management, and utilization can help achieve the success of a program. In line with previous research that posyandu is expected to be able to organize five priority programs, namely maternal and child health, family planning, nutrition improvement, immunization, 
and diarrhea prevention. Availability of adequate facilities and infrastructure, optimal management, and utilization can help achieve the success of a program. In line with previous research that posyandu is expected to be able to organize five priority programs, namely maternal and child health, family planning, nutrition improvement, immunization, and diarrhea prevention. Availability of adequate facilities and infrastructure, optimal management, and utilization can help achieve the success of a program. ${ }^{14}$

\section{Fund}

After competent human resources and complete infrastructure are needed, funds are also needed to support the implementation of a policy or program, because it will become complicated when realizing policy objectives when the funds needed are not sufficient to finance the entire series of activities of a program. In the implementation of the program to improve malnutrition, malnutrition, and stunting at the Health Office of Central Buton District, it is known that some program implementers have stated that the funds are not fully sufficient to carry out innovative activities such as cross-sector socialization, making posters and campaigns on improving nutrition, especially stunting toddlers. Based on secondary data, funds for the nutrition improvement program for children under five at the central Buton District Health office are around Rp. $10.100,000.00$ in 2018, the lack of funds could be one of the causes for not maximizing the achievement of health development targets in the Central Buton District. Following previous research, although the availability of health service Facilities continues to increase, if this availability is not supported by the quality of health service in terms of human resources and financial support, it can result in the implementation of policies/programs being hampered in achieving goals because insufficient funds will affect the quality implementation of programs in the community. ${ }^{15}$

\section{Planning}

Based on the previous research, planning must be clear, both in terms of budget, human resources, and implementation targets according to the target, such as the activity plan for the empowerment team for family welfare is always synergized with the work plan and budget for regional work units. ${ }^{16}$ The Health Office of Central Buton District has established a concept to minimize the problem of nutritional status in toddlers, especially stunting, by determining the structure of the program implementation where the person in charge of the program is the nutrition staff at the health office, and the person in charge at the puskesmas level is the puskesmas nutrition officer. In this case, the health office nutrition staff is tasked with providing technical field guidance and making reports to be accountable to the section head, while the puskesmas is in charge of executing activities and goes directly to the community, together with health or community cadres who have been empowered and become partners for the puskesmas as a community mobilizer around them to care about the health and take part in the utilization of the health services provided, Also, other crossprograms are also involved, such as medical personnel, paramedics, environmental health and community health centers, but this has not been involved in other sectors. The target in implementing the program is toddlers with nutritional problems, as for the target plan, which is to reduce underweight toddlers to $5.3 \%$, wasting toddlers $2.7 \%$, and stunting toddlers $14 \%$ in 2019.

For budget planning is prepared a year before the implementation of the program carried out by the nutrition staff of the health office then the budget activity plan (RKA) is submitted to the government, usually the budget that comes out is less than the planned budget, after which the budget is reported in the form of a budget utilization document (DPA). ) by the nutrition staff of the Health Office of Central Buton District. The Monitoring Plan will be carried out every quarter and evaluation is carried out once a year, namely at the end of the activity or towards the end of the year. To get maximum activity results, planning must be formulated clearly so that the process runs systematically, in other words, managerial planning will provide a comprehensive perspective on the activities to be carried out, both resources, time, or implamentation. ${ }^{17}$

\section{Organizing}

Based on the results of the research on the organization of the nutrition improvement program for children under five at the Health Office of Central Buton District, it is described in several stages, namely the division of tasks, the determination of the coordinator, and the activities to be carried out. The nutrition improvement program for children under five at the Health Office of Central Buton District is carried out following the existing organizational structure at 
the Health Office and in its implementation, it involves various parties, both from the scope of the health office and from the scope of the village / kelurahan. The nutrition improvement program that is implemented as the policyholder is the Head of the Health Office of Central Buton District, then the authority for its implementation is handed over to the public health sector which houses 3 sections, namely, the family health and nutrition section, the health promotion section, and the environmental health section.

Then regarding the division of tasks and responsibilities in implementation, it is entirely up to the puskesmas because there are already nutrition officers or regional supervisors whose job is to monitor the development of nutrition in their area. Based on the policy of the Health Office of Central Buton District government that all health workers at the health center, whether midwives, nutrition workers, or other health workers must cooperate in efforts to treat cases of nutrition in children under five, both in the form of screening and tracking, but the Health Office has not been able to cooperate with other people. other sectors/stakeholders, due to the lack of funds for socialization and advocacy. ${ }^{18}$

\section{Implementation}

The implementation of the program is one indicator of the success of a program because the success of the program will be obtained if the planned program can be implemented properly. The implementation of the nutrition improvement intervention program for malnourished children under five, malnutrition and stunting at the Central Buton district health office is by monitoring the nutritional status of children under five at the posyandu, screening for cases of malnourished children under five, and providing additional food for malnourished toddlers. From the results of the study, it was found that growth monitoring at the posyandu consisted of weighing children under five, measuring the height of toddlers which was carried out every month by posyandu cadres together with puskesmas officers, consisting of midwives, nutrition implementing officers, and nurses, giving vitamins and medicines, supplementary feeding for toddlers, as well as monitoring the growth of children under five with stunting, wasting, underweight to prevent and improve the nutritional status of children under five. Growth monitoring is a follow-up to policies and programs at the community level so that people have the power and efforts to address health problems so that nutritional problems can be resolved properly. Apart from that, the selection is also carried out to trace cases of malnourished toddlers, so that all mothers of toddlers routinely take their children to the posyandu. The implementation of screening is carried out in two stages, the first is that the screening is carried out every two months at the posyandu, secondly, the screening is carried out at the health center when the toddler visits the health center to have his disease checked and the health worker knows that the toddler is suffering from malnutrition

To fulfill and improve the nutritional status of children under five, nutrition officers together with posyandu cadres provide additional food for toddlers. The categories for under-nutrition and stunting children were given additional food in the form of biscuits which were given by cadres at the posyandu, while toddlers with cases of malnutrition were given factory food, biscuits, milk, eggs, and local food if there was assistance from the village / kelurahan. as well as educating mothers of toddlers on providing nutritious foods both at the community center at their home. Apart from that, nutrition workers at the health center, as well as from the local government office, also conduct home visits to malnourished toddlers every week for 3 months to find out the progress and monitor the growth of toddlers by measuring $\mathrm{BH}, \mathrm{BW}$, Lila, and head circumference of toddlers, as well as monitoring the environment where toddlers live. ${ }^{19}$

\section{Evaluation monitoring}

Monitoring evaluation is very necessary so that the implementation stage can run well and on target according to the program plan. Based on the results of the study, it was found that in the nutrition improvement program for children under five, the health department also carried out a monitoring stage which was carried out every quarter, monitoring was carried out by the health office based on the activity report of the puskesmas because from these reports the health department nutrition staff could find out and supervise the program activities and prevent any deviations in the field. If irregularities are found during supervision, the service office can make corrections as soon as possible so that activities can return to the predetermined path. The monitoring stages are also leveled from the posyandu level, the puskesmas level, and the health department level. Monitoring by the Health Office can be carried out in 2 stages, namely direct visits or by observing the results of the activity report. Monitoring is the process of observing activities on an ongoing basis to minimize any deviations because 
if there are deviations, modifications or changes are needed so that implementation remains on the planned path. ${ }^{20,21}$

In addition to monitoring, the Health Office also conducts an evaluation every once a year, the evaluation is carried out at the end of the year, but if there is an extraordinary event (KLB) in an area, we usually do an evaluation as well. Evaluation is carried out in meetings and meetings at the Health Office, where at the meeting each program holder describes the results of the achievement of the implementation of activities as well as obstacles during program implementation. The evaluation of the results obtained from the implementation of the nutrition improvement program for children under five at the Health Office of Central Buton District consisted of the results of monitoring the status of toddlers at the center, the results of the screening of cases of malnutrition, the results of the provision of additional food for undernutrition, malnutrition, and stunting in the district. Central Buton, If there are indicators that have not met the target, an evaluation meeting is held at the health department level, to find out the obstacles and how to overcome them so that the target year can be achieved in the next implementation. The health office as the holder of the authority for the nutrition improvement program plays a full role in observing all existing activities in the field by continuing to coordinate with the puskesmas and cadres so that problems that occur can be minimized properly. ${ }^{22}$ Evaluation is an orderly and systematic process of comparing the results achieved with the benchmarks set criteria, then drawing conclusions based on suggestions and input from each program implementer, because it will be difficult to know the extent to which the objectives of the planning are achieved if no evaluation is carried out. ${ }^{23}$

\section{Output}

Nutrition status monitoring activities are actively carried out by nutrition officers at the health center through the weighing month for under-fives which is carried out twice a year. The state of poor nutrition will reduce the body's resistance which will cause children to get sick easily, resulting in death. Prevention of cases of malnutrition, deficiency, and stunting is carried out by providing additional food (PMT) which is funded through the Central Buton Regency APBD and Southeast Sulawesi Provincial APBD, PMT which is given in the form of milk, MP-ASI biscuits, and milk porridge. Almost all of the cases assisted had gained weight. Prevention of malnutrition under five who require treatment is carried out at the health center, but if there is a congenital disease, the toddler is referred to the Central Buton Hospital.

\begin{tabular}{ccc}
\hline $\begin{array}{c}\text { Nutritional } \\
\text { status }\end{array}$ & $\mathbf{2 0 1 7}$ & $\mathbf{2 0 1 8}$ \\
\hline Underweight & $25.9 \%$ & $17 \%$ \\
Stunting & $48.8 \%$ & $28 \%$ \\
Wasting & $13.3 \%$ & $9.5 \%$ \\
\hline
\end{tabular}

Based on the results of research and primary data, it is revealed that all toddlers with nutritional problems have received $100 \%$ treatment, so there is an increase in the nutritional status of toddlers in 2018, which is marked by a very significant decrease in the problem of nutritional status of children from 2017-1018. In addition, there was an increase in the coverage of under-fives weighing, where the frequency of underfive visits to posyandu in 2017, from 12,060 the number of toddlers, with the coverage of under-five weighed as much as 8,786 (73\%) and 3,247 (27.14\%) under-fives whose body weight was not monitored, while in 2018 The number of toddlers weighed was 10,870 children with a community participation level of $85.7 \%$ of the results obtained, exceeding the national target that has been set, namely $80 \%$, and exceeding the scope of achievement in 2017. ${ }^{10}$

\section{CONCLUSIONS}

The nutrition improvement program for children under five in Central Buton District still has several unfulfilled aspects, such as a lack of human resources in quantity and quality, a lack of budget for nutrition improvement programs, which is only around Rp. $10,100,000.00$ in 2018 , lack of socialization, especially stunting across other sectors, as a result, the problem of stunting in Central Buton Regency is the highest in the Southeast Sulawesi province in 2018, for that the local government needs to make even better efforts.

There is still a need for training for nutrition staff at the Health Office and Nutrition Implementers at health centers, need to increase health funds from the APBD for health development programs, especially community nutrition, need cross-sector and crossprogram cooperation in reducing nutrition problems in children under five in Central Buton district, and increasing utilization and socialization of cadres to mothers of children under five so that local communities have higher motivation in efforts to 
improve health status both within the family and in the community.

\section{REFERENCES}

1. Mitra. Permasalahan Anak Pendek ( Stunting) dan Intervensi untuk Mencegah Terjadinya Stunting (Suatu Kajian Kepustakaan). J Kesehat Komunitas. 2015;2(5):254-61.

2. Renyoet BS, Nai HME. Estimasi potensi kerugian ekonomi akibat wasting pada balita di indonesia. $\mathbf{J}$ Gizi Indones. 2019;7(2):127.

3. Kementerian Kesehatan Republik Indonesia. Bersama Cegah Stunting. 2018;(Warta Kesmas Tahun 2018).

4. Khoeroh H, Indriyanti D. Evaluasi Penatalaksanaan Gizi Balita Stunting. Unnes J Public Heal. 2017;6(3).

5. Kementerian Kesehatan Republik Indonesia. Gizi, Investasi Masa Depan Bangsa. 2017; (Warta Kesmas Tahun 2017).

6. Zilda O, Sudiarti T. Faktor Risiko Stunting pada Balita (24-59 Bulan) di Sumatera. J Gizi dan Pangan. 2013;8(3):175-80.

7. Badan Penelitian dan Pengembangan Kesehatan. Kementerian Kesehatan. Has Utama Riskesdas 2018. 2018;

8. Gizi Masyarakat D, Jenderal KM D, Kesehatan RI K. Hasil Pemantauan Status Gizi ( PSG ) Tahun 2017. Buku saku pemantauan Status Gizi. 2017;

9. Rosha CH B, Sari K, Yunita SP I, Amaliah N, Utami N. Peran Intervensi Gizi Spesifik dan Sensitif dalam Perbaikan Masalah Gizi Balita di Kota Bogor. Bul Penelit Kesehat. 2016;44:12738.

10. Dinas Kesehatan Kabupaten Buton Tengah. Profil Kesehatan Kabupaten Buton Tengah Tahun 2018. 2019;

11. Menteri Kesehatan Republik Indonesia. Peraturan Menteri Kesehatan Republik Indonesia Nomor 23 Tahun 2014. 2014;

12. Peraturan Menteri Kesehatan RI No 26 tahun 2003. Penyelenggaraan Pekerjaan dan Praktik Tenaga Gizi. 2013.

13. Sugiarto A, Retnaningsih $C$, Indrayati $Y$. Pendayagunaan Bidan Sebagai Tenaga Kesehatan Di Puskesmas dalam pelaksanaan kebijakan upaya perbaikan gizi pada balita di Kabupaten Buton Tengah Provinsi Sulawesi Tenggara. Soepra J Huk Kesehat. 2018;4(1):1-17.

14. Boli EB, Baliwati YF, Sukandar D. Komitmen
Politik dan Peluang Pengembangan Kebijakan Gizi Pemerintah Daerah Provinsi Nusa Tenggara Timur Political Commitment and Opportunity to Advance Nutrition Policy in East Nusa Tenggara Province. J MKMI. 2018;14(4):351-9.

15. Subarsono. Analisis Kebijakan Publik. Pelajar P, editor. Yogyakarta; 2012.

16. Tomi S, Dian H, Soemarno. Evaluasi Program Perbaikan Gizi Masyarakat (Penanggulangan Gangguan Akibat Kekurangan Iodium ) di Kota Malang. J Pembang Dan Alam Lestari. 2016;7(1):44-51.

17. Azwar A. Pengantar Administrasi Kesehatan. Bina Rupa Aksara, editor. jakarta; 2012.

18. Sutisna. Manajemen Kesehatan. UNS, editor. surakarta; 2009.

19. Febry F. Jurnal Ilmu Kesehatan Masyarakat. 2014;3(November 2012).

20. Sulaeman S E. Manajemen Kesehatan Teori dan Praktik di Puskesmas Yogyakarta. Yogyakarta: Gadja Mada University Press; 2011.

21. Wijayanti T, Niken P. Studi Kualitatif Proses Asuhan Gizi Terstandar Di Ruang Rawat Inap Rs St. Elisabeth Semarang. J Nutr Coll. 2013;2(1):170-83.

22. Sawitri N. Pelaksanaan Program Perbaikan Gizi Masyarakat Oleh Dinas Kesehatan Kota Pekanbaru. J JOM Fisip. 2018;Vol. 5 No.(1):Hal : 1-15.

23. Sarwono J. Metode Penelitian Kuantitatif dan Kualitatif. In: Graha Ilmu. Yogyakarta; 2006.

Copyright (C) 2021; Jurnal Gizi Indonesia (The Indonesian Journal of Nutrition), Volume 9 (2), 2021

e-ISSN : 2338-3119, p-ISSN: 1858-4942 